The University of Maine

\title{
DigitalCommons@UMaine
}

Scientific Articles

Publications

Winter 12-21-2011

\section{Utilization of waste from a marine recirculating fish culture system as a feed source for the polychaete worm, Nereis virens}

\author{
NIcholas Brown \\ npbrown@maine.edu \\ Stefanie Plaud \\ Stephen Eddy
}

Follow this and additional works at: https://digitalcommons.library.umaine.edu/ari_articles

\section{Repository Citation}

Brown, NIcholas; Plaud, Stefanie; and Eddy, Stephen, "Utilization of waste from a marine recirculating fish culture system as a feed source for the polychaete worm, Nereis virens" (2011). Scientific Articles. 5.

https://digitalcommons.library.umaine.edu/ari_articles/5 


\title{
Utilization of waste from a marine recirculating fish culture system as a feed source for the polychaete worm, Nereis virens
}

\author{
Nicholas Brown *, Stephen Eddy, Stefanie Plaud \\ University of Maine, Center for Cooperative Aquaculture Research, Salmon Farm Road, Franklin, ME 04634, United States
}

\section{A R T I C L E I N F O}

\section{Article history:}

Received 17 November 2009

Received in revised form 9 September 2011

Accepted 12 September 2011

Available online 29 September 2011

\section{Keywords:}

Marine polychaete

Nereis virens

Recirculation

Integrated aquaculture

Polyculture

Nutrient recycling

\begin{abstract}
A B S T R A C T
Two experiments were conducted to test the effect of feeding the polychaete worm Nereis virens with solid wastes collected from a marine recirculating system. In experiment 1, worms with an initial mean weight of $0.37 \mathrm{~g}$ were fed for 80 days with a commercial worm diet (CD), halibut fecal waste (FW), uneaten halibut feed pellets (PW) or a 1:1 mixture of fecal waste and feed pellet waste (MW). The resulting biomass and average weight of harvested worms was significantly higher in the PW group than in the other 3 groups (ANOVA, $\mathrm{p}<0.05$ ). Total fat levels in the worms from the MW and PW groups were higher than the CD group. In a similar setup for experiment 2 , worms with an initial mean weight of $0.18 \mathrm{~g}$ were fed varying proportions of waste mixed with commercial worm diet. The CD group was fed only commercial diet, the W100 group fed only waste and two intermediate treatments fed 50\% of each (W50) or 75\% waste (W75). Total fat content of the worms was significantly higher in the W75 and W100 groups than the CD group. There were no significant differences in terms of biomass or average weight at the end of the experiment. CHN analysis of the remaining substrate after harvest revealed that little in the way of organic content was left behind.

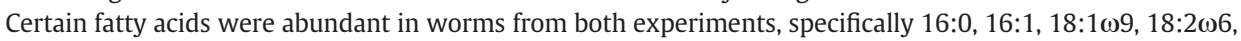
20:5 $\omega 3$ (EPA) and 22:6 $\omega 6$ (DHA) and analysis revealed some treatment differences due to diet. The results demonstrate that production of $N$. virens using fish wastes is highly efficient. This species is an excellent candidate for integrated aquaculture and waste recycling.
\end{abstract}

(C) 2011 Published by Elsevier B.V.

\section{Introduction}

Treatment methods in land based recirculating systems include filters to trap and concentrate solid wastes. These wastes consist of uneaten feed and fecal material which both contain nutrients which represent a potential feed source. Organisms that might feed on this waste include deposit feeding detritivores such as polychaete worms. The potential for polychaete worms to ingest and assimilate fecal waste from Japanese flounder was shown by Honda and Kikuchi (2002). In more recent studies, trials have been conducted using Nereis diversicolor, a closely related species to Nereis virens. García-Alonso et al. (2008) assessed the possible culture of this species using eel sludge as a feed source and Bischoff et al. (2009) cultured $N$. diversicolor in settlement tanks receiving sludge from a sea bream recirculation system. Palmer (2010) assessed the growth and survival of two polychaetes Perinereis nuntia and Perinereis helleri cultured in sand beds receiving wastes from ponds holding prawns. Earlier work by Tenore et al. (1974) demonstrated that $N$. virens and Capitella capitata could be grown in combination with the oyster, Crassostera virginica. Aquatic worms also show great potential for bioremediation of deposited

\footnotetext{
* Corresponding author. Tel.: +1 207422 9096; fax: +1 2074228920

E-mail address: npbrown@maine.edu (N. Brown).
}

wastes from net pens or in fish ponds (Kinoshita et al., 2008; Riise and Roos, 1997) and they play an important role in natural ecosystems in the decomposition and mineralization of organic material. Their abundance and activity can be critical in the recovery of impacted coastal aquaculture sites (Heilskov et al., 2006) and measurements of the relative abundance of these worms can be used to indicate the impact of coastal aquaculture operations (Tomasseti and Porrello, 2005).

Certain polychaete worms are highly valued as bait and as aquaculture feeds and are cultured commercially (D'Asaro, 1976; Fidalgo e Costa, 1999; Olive, 1999). Nereid worms are valued by the industry as excellent sources of polyunsaturated fatty acids (PUFAs), and they have the potential to supplement fish oil as sources of essential lipid components of feeds (Fidalgo e Costa et al., 2000; Lytle et al., 1990; Olive et al., 2000). These fatty acids play an important role in determining broodstock and larval performance in both cultured marine fish and panaeid shrimp (Izquierdo et al., 2001; Wouters et al., 2001). Fishmeal and fish oil are used in the diets of aquaculture species in large part because of the fact that they are an excellent source of these PUFAs and also proteins with suitable amino acid profiles. The ability to re-capture these valuable nutrients efficiently from fish production waste streams might help to improve sustainability in integrated aquaculture processes.

In this study we examined the growth and resulting nutritional composition of cultured $N$. virens fed waste from a recirculation 
system holding juvenile Atlantic halibut Hippoglossus hippoglossus. We conducted two experiments. Experiment 1 was designed to assess halibut fecal waste and/or uneaten fish feed as a worm diet compared to a formulated polychaete diet. In experiment 2 we examined the performance of worms fed varying proportions of waste combined with a formulated polychaete diet. Using the results from the two experiments we assessed the costs and potential benefits in terms of waste treatment/mitigation and economic return from using these polychaete worms as a component of an integrated aquaculture system.

\section{Materials and methods}

\subsection{Experimental system description}

The experimental worm culture system consisted of twelve identical rectangular tanks or raceways $(180 \mathrm{~cm} \times 70 \mathrm{~cm} \times 29 \mathrm{~cm})$ arranged in two levels of six tanks, all of which were connected to a single recirculation system. The tank system was contained in a dedicated temperature controlled room illuminated with overhead fluorescent lights controlled by an electronic timer. The lighting was $12 \mathrm{~h}$ light: $12 \mathrm{~h}$ dark. Water entered each tank through a spray bar mounted at one end and left the tank through a surface drain at the other end. The water depth was set at $4 \mathrm{~cm}$ above the substrate, which consisted of a layer of sand/fine gravel approximately $8 \mathrm{~cm}$ deep throughout the tank. The water flow was maintained at approximately $2 \mathrm{~L} / \mathrm{min}$ to each tank. Water leaving the tanks was collected in a common sump $(340 \mathrm{~L})$ and from there it was pumped (Dayton $3 / 4$ HP centrifugal pump, Grainger Industrial Supply, Warren, ME, USA) through a sand filter (Tagelus TA 35D, Aquatic Ecosystems, Apopka, FL, USA), a U.V. sterilizer (Gamma 1401 15W, Aquatic Ecosystems, Apopka, FL, USA), a foam fractionator (Aqua C, Aquatic Ecosystems, Apopka, FL, USA) and finally up to a $100 \mathrm{~L}$ header tank, where it was then distributed back to the tanks by gravity. Ozone from an ozone generator (Aquazone Plus 200 Red Sea 8985, Aquatic Ecosystems, Apopka, FL, USA) was injected into the foam fractionater and ozone output was regulated to maintain an ORP of $400 \mathrm{mV}$. New seawater was added to the system at a rate of approximately $5 \%$ of the total system volume per day. Water quality measurements were made weekly using a Hach spectrophotometer (Odyssey DR 2500, Hach Company, Loveland, CO, USA); for ammonia (salicylate method \#8155), for nitrate (cadmium reduction method \# 8192) and for nitrite (diazotization method \# 8507). Temperature and dissolved oxygen were recorded daily using a handheld meter (Oxyguard Handy Gamma, Point Four Systems, BC, Canada).

\subsection{Feeds}

In experiment 1 the worms were fed a commercial worm diet, halibut feces, or uneaten waste halibut feed once per day according to the treatment group. In experiment 2 the worms were fed a commercial worm diet, composite waste (waste feed and feces), or different combinations of the worm diet and waste. In both experiments feed levels were increased across treatments to overall appetite of the worms as indicated by condition of the beds. Signs of overfeeding (build up of feed, overgrowth of bacteria resulting in white, black or sometimes red bacterial mats) in any tank resulted in a reduction in feed across replicates so that replicate tanks were always fed identical amounts of feed.

The commercial worm diet used in both trials was manufactured by Ziegler Brothers (Gardners PA, USA) with a pellet size of $0.8 \mathrm{~mm}$ and a proximate composition of $34 \%$ crude protein and $9 \%$ crude fat.

The fish waste used in both trials as feed for the worms in the experimental groups was collected daily from a recirculating halibut nursery. This system held a maximum of about $2000 \mathrm{~kg}$ of juvenile halibut in ten tanks. The water leaving these tanks all drained through a parabolic screen filter $(300 \mu \mathrm{m})$ for solids removal. The halibut were fed daily to satiation with a formulated feed manufactured by Northeast Nutrition (New Brunswick, Canada) with a pellet size of $5 \mathrm{~mm}$ and proximate composition of $50 \%$ crude protein and $20 \%$ crude fat. The fecal waste was collected from the parabolic filter in the morning before the halibut were fed, and was passed through a $1 \mathrm{~mm}$ sieve to remove any uneaten feed pellets, which may have collected overnight. Uneaten waste feed pellets were collected from the filter in the afternoon one to two hours after the halibut were fed and sieved to remove the finer particulate matter and fecal waste.

\subsection{Analyses}

Composite samples $(n=5)$ of fish waste, collected over the course of $24 \mathrm{~h}$, were analyzed for moisture and proximate composition by New Jersey Feed Laboratory, Trenton, New Jersey. Crude protein was analyzed using a Kjeltec Auto 1030 Analyzer (Tecator, Hoganas, Sweden). Ash content was measured using American Oil Chemists Society (AOCS, 2009) method \#942.05 after heating a feed sample at $600{ }^{\circ} \mathrm{C}$ for $12 \mathrm{~h}$ until carbon free. Crude lipid was determined gravimetrically following extraction in dichloromethane using a Soxtec HT2 apparatus (Foss, Eden Prairie, MN, USA).

Table 1 shows the proximate composition and calculated gross energy content of the diets used in both experiments.

At the completion of each experiment, all worms were harvested from the beds by sieving through screens. Total wet weight was measured and 50 individual worms from each replicate bed were individually weighed (blotted wet weight). The 50 worms collected for individual weight measurement were then analyzed for proximate composition as above. Fatty acid profiles were also analyzed at the same laboratory by GLC according to the AOCS method \# Ce 1b-89 (AOCS, 2009).

At the conclusion of experiment 2 (but not experiment 1), three core samples of substrate measuring $19 \mathrm{~mm}$ in diameter from surface to tank base (approximately 50 g per core), were collected at the top, middle and outlet end of each bed. These were frozen for subsequent

Table 1

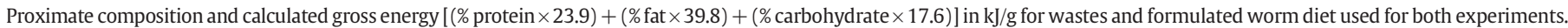
Values are mean percentages of 5 samples (except formulated worm feed where $n=1$ ). Standard errors of means are given in parentheses.

\begin{tabular}{|c|c|c|c|c|c|c|c|}
\hline Feed type & & Moisture (\%) & Protein (\%) & Fat $(\%)$ & $\mathrm{CHO}(\%)$ & Ash (\%) & Gross energy $(\mathrm{kJ} / \mathrm{g})$ \\
\hline \multirow[t]{2}{*}{ Formulated worm diet } & Wet & 9.91 & 34.90 & 9.83 & 37.35 & 8.01 & 18.8 \\
\hline & Dry & & 38.74 & 10.91 & 41.46 & 8.89 & \\
\hline \multirow[t]{2}{*}{ Fecal waste (Exp 1) } & Wet & $80.41(1.54)$ & $9.72(1.07)$ & $4.32(1.11)$ & $0.27(1.23)$ & $5.27(0.29)$ & 4.1 \\
\hline & Dry & & 49.63 & 22.06 & 1.40 & 26.92 & \\
\hline \multirow[t]{2}{*}{ Mixed waste (1:1) (Exp 1) } & Wet & $68.22(2.23)$ & $16.42(0.94)$ & $7.02(0.24)$ & $2.97(1.33)$ & $5.37(0.17)$ & 7.2 \\
\hline & Dry & & 51.67 & 22.08 & 9.34 & 16.91 & \\
\hline \multirow[t]{2}{*}{ Pellet waste (Exp 1) } & Wet & $53.35(2.93)$ & $24.62(1.43)$ & $10.04(0.69)$ & $6.23(0.67)$ & $5.76(0.25)$ & 11.0 \\
\hline & Dry & & 52.78 & 21.53 & 13.36 & 12.34 & \\
\hline \multirow[t]{2}{*}{ Mixed waste (Exp 2) } & Wet & $61.88(1.10)$ & $18.20(0.64)$ & $8.80(0.31)$ & $5.90(1.37)$ & $4.93(0.17)$ & 8.9 \\
\hline & Dry & & 48.11 & 23.26 & 13.03 & 13.03 & \\
\hline
\end{tabular}


CHN analysis. Freeze dried samples were sifted through a $1 \mathrm{~mm}$ sieve. The $<1 \mathrm{~mm}$ fraction was finely ground, oven dried $\left(60{ }^{\circ} \mathrm{C}\right.$ for $6 \mathrm{~h}$ ) and then further dried in a dessicator. The samples were analyzed for carbon and nitrogen with a Perkin-Elmer 2400 Series II CHNS/O analyzer (Waltham, MA, USA). Proximate composition of the substrate samples was analyzed using the same methods as for the worms. Additionally acid insoluble ash was measured using AOCS method \#920.08 (AOCS, 2009). A weighed sample was incinerated at $600{ }^{\circ} \mathrm{C}$ for $2 \mathrm{~h}$ or until ash is carbon free, as in the "Ash" method. The remaining mass (ash) is dissolved with boiling hydrochloric acid on a hot plate. This is filtered and washed with boiling distilled water, the remaining residue being acid insoluble ash.

\subsection{Experiment 1}

The worms used in the study were reared at the University of Maine's Center for Cooperative Aquaculture Research facility located in Franklin, Maine.

In experiment 1 , juvenile worms of $0.37 \mathrm{~g}$ average weight were used and a total biomass of $407 \mathrm{~g}$ was stocked into each tank (approximately 1018 worms per bed). Four treatment groups were assigned randomly amongst the tanks with three replicate tanks per treatment. The $\mathrm{CD}$ (control diet) group was fed the commercial worm diet. The other three groups were fed solid wastes collected as described from the halibut recirculation system.

Group FW (fecal waste) was fed only fecal wastes, group MW (mixed waste) was fed a 1:1 mixture by weight of fecal waste and uneaten halibut feed pellet waste and group PW (pellet waste) was fed only waste feed pellets. The three beds in the CD group received a ration of $6 \mathrm{~g}$ per day each at the start of the experiment gradually increasing to a maximum of $38 \mathrm{~g}$ per day during the 80 day trial. The minimum and maximum wet weight daily rations in the MW, FW and PW groups were $27 \mathrm{~g}$ and $113 \mathrm{~g}$ (MW), $27 \mathrm{~g}$ and $198 \mathrm{~g}$ (FW) and $27 \mathrm{~g}$ and $126 \mathrm{~g}$ (PW).

\subsection{Experiment 2}

In experiment 2, $254 \mathrm{~g}$ of juvenile worms with an average start weight of $0.18 \mathrm{~g}$ were distributed into each of the 12 experimental tanks (approximately 1270 worms per bed). Four treatment groups were assigned randomly to the tanks, with three replicate tanks per treatment. The CD group was fed the same commercial worm feed as in experiment 1 . The other three groups were fed varying levels of waste alone or in combination with the commercial worm diet. Waste sludge from the halibut system was collected from the parabolic filter throughout the day so as to obtain a mixture of uneaten feed and fecal waste. This was thoroughly mixed before feeding directly to the worm beds. Group W100 was fed only waste, group W75 was fed $75 \%$ of the amount of waste W100 received and $25 \%$ of the formulated feed that the $\mathrm{CD}$ group were fed. Group W50 received $50 \%$ of the waste that the $\mathrm{W} 100$ group received and $50 \%$ of the formulated feed that the $\mathrm{CD}$ group received. The $\mathrm{CD}$ group was fed only formulated worm feed. The waste was fed in wet form and dispensed evenly onto the beds using a large syringe, and the commercial worm feed was fed dry, sprinkled over the beds. The initial and final feed rations in the $\mathrm{CD}$ group were $6 \mathrm{~g}$ and $28 \mathrm{~g}$ per bed respectively. In the W100 group, the initial and final feed rations were $54 \mathrm{~g}$ and $126 \mathrm{~g}$ respectively. The experiment continued for 71 days after which all worms were harvested from the beds.

\subsection{Calculations}

For both experiments:

Biomass gain (g) = Final biomass (g)-Initial biomass (g).

The specific growth rate (SGR) was calculated from the formula:

$S G R=100 \times \frac{[\log (\text { Initial weight }(\mathrm{g})]-[(\log (\text { Final wt }(\mathrm{g})]}{\text { Time }(\text { days })}$

To calculate feed conversion ratio (FCR), the amount of waste fed was adjusted to the same moisture content as the formulated worm $\operatorname{diet}(9.91 \%)$.

$F C R=\frac{\text { feed consumed }(\mathrm{g} \text { dry feed equivalent })}{\text { biomass gain }(\mathrm{g})}$

Average worm protein tissue content (Table 2) was multiplied by average weight gain to give average increase in tissue protein per tank for each treatment group. Productive protein value (PPV, \%) was calculated as follows:

$$
P P V=\frac{\text { increase in tissueprotein }(\mathrm{g})}{\text { protein consumed }(\mathrm{g})} \times 100
$$

\subsection{Statistical analyses}

The SYSTAT program was used for statistical analysis. Data on average individual weights, final biomass, and levels of fatty acids in the worms between treatments were analyzed using a nested one-way analysis of variance (GLM). Data were first tested for normality using the Kolmogorov-Smirnov test. Post hoc separation of means among treatments was done using Tukeys HSD. Since percentage data have a tendency to form a binomial distribution rather than a normal distribution, all percent data $(\mathrm{p})$ were arcsine transformed prior to statistical analyses using the equation: Trans $(p)=180 / \Pi \times \operatorname{arcsine}\left((p / 100)^{0.5}\right)$.

\section{Results}

\subsection{Experiment 1}

\subsubsection{Water quality}

In experiment 1 , the mean temperature was $14.1^{\circ} \mathrm{C} \pm 0.36$ and ranged between $5.6^{\circ} \mathrm{C}$ and $18.0^{\circ} \mathrm{C}$. Between days 41 and 63 there were problems with temperature control which resulted in a

Table 2

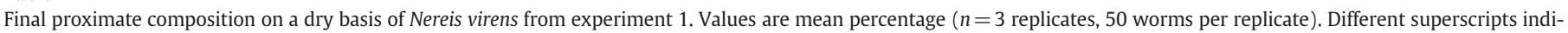
cate significant differences between treatments (ANOVA, $\mathrm{p}<0.05$ ). Standard errors of means are given in parentheses.

\begin{tabular}{|c|c|c|c|c|c|}
\hline & Treatment group & Protein (\%) & Fat $(\%)$ & Carbohydrate (\%) & Ash (\%) \\
\hline \multirow[t]{4}{*}{ Experiment 1} & Commercial worm diet (CD) & $61.9^{\mathrm{a}}(0.32)$ & $19.2^{\mathrm{b}}(0.11)$ & $16.8(0.31)$ & $17.8^{\mathrm{ab}}(0.59)$ \\
\hline & Fecal waste (FW) & $56.8^{\mathrm{b}}(1.56)$ & $19.7^{\mathrm{b}}(0.56)$ & $12.5(0.90)$ & $21.9^{\mathrm{a}}(1.85)$ \\
\hline & Mixed waste (MW) & $59.6^{\mathrm{ab}}(0.80)$ & $23.6^{\mathrm{a}}(0.48)$ & $14.4(0.29)$ & $14.8^{\mathrm{b}}(0.49)$ \\
\hline & Pellet waste (PW) & $60.9^{\mathrm{ab}}(0.78)$ & $22.3^{\mathrm{ab}}(0.45)$ & $16.3(1.57)$ & $15.6^{\mathrm{b}}(1.11)$ \\
\hline \multirow[t]{4}{*}{ Experiment 2} & $\mathrm{CD}$ & $54.99(0.01)$ & $12.86^{\mathrm{a}}(0.01)$ & $13.44(0.00)$ & $17.97(0.01)$ \\
\hline & W50 & $53.93(0.01)$ & $12.98^{\mathrm{ab}}(0.01)$ & $11.45(0.01)$ & $20.92(0.02)$ \\
\hline & W75 & $54.04(0.02)$ & $14.28^{\mathrm{ab}}(0.01)$ & $10.54(0.01)$ & $20.52(0.03)$ \\
\hline & W100 & $53.96(0.00)$ & $16.02^{\mathrm{b}}(0.01)$ & $10.54(0.01)$ & $18.74(0.01)$ \\
\hline
\end{tabular}


decrease in temperature. The mean dissolved oxygen concentration was $7.3 \mathrm{mg} / \mathrm{L} \pm 0.18$ and ranged between 3.6 and $10.6 \mathrm{mg} / \mathrm{L}$. Total ammonia ranged from 0.25 to $0.6 \mathrm{mg} / \mathrm{L}$ (mean $0.43 \mathrm{mg} / \mathrm{L} \pm 0.04$ ), nitrite concentration ranged between 0.03 and $0.22 \mathrm{mg} / \mathrm{L}$ (mean $0.11 \mathrm{mg} / \mathrm{L} \pm 0.02$ ) and nitrate concentration ranged from $0.1 \mathrm{mg} / \mathrm{L}$ to $0.9 \mathrm{mg} / \mathrm{L}$ (mean $0.6 \mathrm{mg} / \mathrm{L} \pm 0.10$ ). $\mathrm{pH}$ ranged from 7.2 to 7.6 (mean $7.44 \pm 0.04)$.

\subsubsection{Proximate composition of worms}

The moisture content ranged from $79.8 \% \pm 0.03$ to $80.7 \% \pm 0.35$. Protein content was significantly higher in the $C D$ group than the FW group (ANOVA, $\mathrm{p}<0.05$, Table 2 ). Fat content was significantly higher in the MW than the FW and CD groups (ANOVA, $\mathrm{p}<0.05$ ) but there were no significant differences in carbohydrate content. Ash content was significantly higher in the FW group than either the MW or PW groups (ANOVA, $\mathrm{p}<0.05$ ).

\subsubsection{Worm growth}

The final average weight and biomass (Table 3 ) were significantly higher in the group fed waste pellets (ANOVA, $\mathrm{p}<0.05$ ).

\subsubsection{Fatty acid analysis}

The values of the 5 most abundant fatty acids for each group are compared graphically across treatments in Fig. 1 along with two other fatty acids of particular interest to nutritionists considering polychaete worms as a feed component for fish or shrimp diets

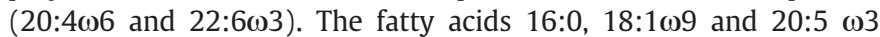
were consistently in the top 5 across treatments. The level of

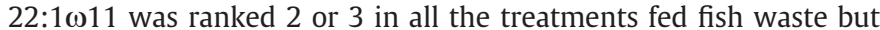
ranked 14 at a much lower level in the CD group. The level of 16:1 was significantly higher in the MW and PW group than the CD group (ANOVA, $\mathrm{p}<0.05$ ). The level of 18:1 $\omega 9$ was significantly higher in the MW and PW groups than either the FW or CD groups (ANOVA,

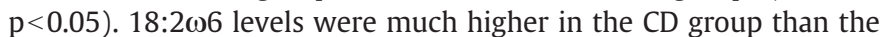

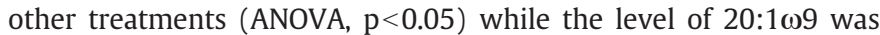
much lower in this group than the other groups and significantly higher in both the MW and PW groups than either the CD or FW groups (ANOVA, $\mathrm{p}<0.05$ ). There were no differences in the level of

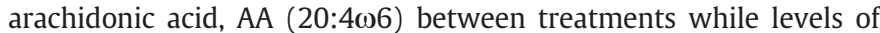
both eicosapentaenoic acid, EPA (20:5 03 ) and docosahexaenoic acid,

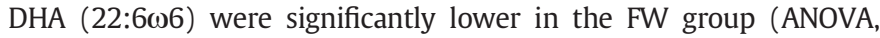
$\mathrm{p}<0.05)$.
The ratio of $\omega 3: \omega 6$ varied from $0.97 \pm 0.01$ to $1.57 \pm 0.06$ and the DHA:EPA ratio was between $0.44 \pm 0.01$ and $0.46 \pm 0.01$ across all groups.

\subsection{Experiment 2}

\subsubsection{Water quality}

During experiment 2 , mean water temperature was $17.9{ }^{\circ} \mathrm{C} \pm 0.09$ and varied between $14.8^{\circ} \mathrm{C}$ and $19.3^{\circ} \mathrm{C}$. Dissolved oxygen concentration was between 4.7 and $8.8 \mathrm{mg} / \mathrm{L}$ (mean $7.2 \mathrm{mg} / \mathrm{L} \pm 0.09$ ). Total ammonia concentration varied between 0.01 and $0.34 \mathrm{mg} / \mathrm{L}$ (mean $0.13 \mathrm{mg} / \mathrm{L} \pm 0.04$.) Nitrate concentration was 0.5 to $2.9 \mathrm{mg} / \mathrm{L}$ (mean $1.21 \mathrm{mg} / \mathrm{L} \pm 0.23$ ) and nitrite concentration was 0.04 to $3.00 \mathrm{mg} / \mathrm{L}$ (mean $0.60 \mathrm{mg} / \mathrm{L} \pm 0.27$ ). $\mathrm{pH}$ ranged between 6.9 to 7.7 (mean $7.39 \pm$ $0.08)$.

\subsubsection{Proximate composition of worms}

The final proximate composition of the worms in each treatment is shown in Table 2. The analysis of variance revealed a significantly higher fat level in the W100 group worms compared to CD group worms (ANOVA, $\mathrm{p}<0.05$ ).

\subsubsection{Worm growth}

The initial and final weights, total biomass gains, FCR and SGR are shown in Table 3. Also presented are the survival rate, final density in terms of $\mathrm{kg} / \mathrm{m}^{2}$ and the total amount of feed given to each treatment group.

Weight gain was over $1000 \%$ over the 71 days in all groups, with no significant differences in average weights or final biomasses between treatments, irrespective of whether worms were fed only waste, only commercial worm feed or a combination.

\subsubsection{Fatty acid analysis}

The values of the 5 most abundant fatty acids as well as AA

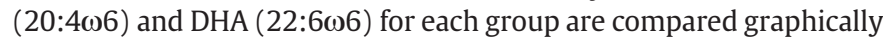
across treatments in Fig. 2.

As in the first experiment, the levels of $18: 2 \omega 6,18: 3 \omega 3$ and 20:2 $\omega 6$ were significantly higher in the CD group than the other treatments (ANOVA, $\mathrm{p}<0.05$ ) and the level of 18:2 $\omega 6$ was significantly lower in the waste-only fed group (W100) than the W50 and W75 groups (ANOVA, $\mathrm{p}<0.05$ ). Again, there were no differences in the level of 20:4 $\omega 6$ between treatments. The levels of $18: 1 \omega 9,20: 5 \omega 3$ and

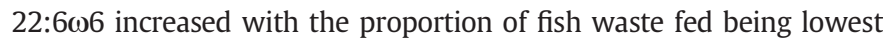
in the CD group and highest in the W100 group.

Table 3

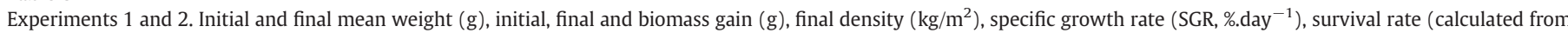

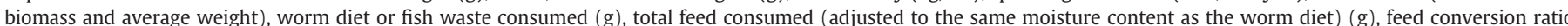


differences (ANOVA, $\mathrm{p}<0.05$ ).

\begin{tabular}{|c|c|c|c|c|c|c|c|c|}
\hline \multirow[t]{2}{*}{ Treatment group } & \multicolumn{4}{|l|}{ Experiment 1} & \multicolumn{4}{|l|}{ Experiment 2} \\
\hline & $\mathrm{CD}$ & FW & MW & PW & $\mathrm{CD}$ & W50 & W25 & W100 \\
\hline Initial weight (g) & 0.37 & 0.37 & 0.37 & 0.37 & 0.18 & 0.18 & 0.18 & 0.18 \\
\hline Final weight (g) & $2.42^{\mathrm{b}}(0.10)$ & $2.17^{\mathrm{b}}(0.07)$ & $2.33^{\mathrm{b}}(0.15)$ & $2.89^{\mathrm{a}}(0.13)$ & $1.95(0.07)$ & $1.93(0.05)$ & $1.93(0.07)$ & $1.95(0.07)$ \\
\hline Initial biomass ( $\mathrm{g}$ ) & 407.0 & 407.0 & 407.0 & 407.0 & 254.0 & 254.0 & 254.0 & 254.0 \\
\hline Final biomass (g) & $1582.1^{\mathrm{b}}(67.3)$ & $1077.6^{\mathrm{b}}(45.6)$ & $1553.1^{\mathrm{b}}(138.7)$ & $2185.6^{\mathrm{a}}(176.6)$ & $2357.0(85.0)$ & $2347.7(45.0)$ & 2284.5 (57.9) & $2430.1(93.5)$ \\
\hline Biomass gain $(\mathrm{g})$ & 1175.1 & 670.6 & 1146.1 & 1778.6 & 2103.0 & 2093.7 & 2030.5 & 2176.1 \\
\hline Final density $\left(\mathrm{kg} / \mathrm{m}^{2}\right)$ & 1.26 & 0.86 & 1.23 & 1.73 & 1.87 & 1.86 & 1.81 & 1.92 \\
\hline SGR $\left(\% \cdot\right.$ day $\left.^{-1}\right)$ & 2.23 & 2.09 & 2.18 & 2.45 & 3.36 & 3.34 & 3.34 & 3.35 \\
\hline Survival rate (\%) & 59.7 & 45.2 & 61.6 & 69.2 & 76.9 & 74.0 & 87.2 & 69.0 \\
\hline Worm diet consumed (g) & 1369.0 & & & & 1234.0 & 596.0 & 466.8 & \\
\hline Waste consumed (g) & & 2916.6 & 3766.7 & 5832.0 & & 2916.6 & 3766.7 & 5832.0 \\
\hline Total feed consumed ( $\mathrm{g}$ ) & 1369.0 & 860.3 & 1570.3 & 3298.5 & 1234.0 & 1231.8 & 1287.9 & 1271.4 \\
\hline Feed conversion ratio (FCR) & 1.16 & 1.28 & 1.37 & 1.85 & 0.59 & 0.59 & 0.63 & 0.58 \\
\hline Increase in tissue protein $(\mathrm{g})$ & 123.4 & 68.6 & 117.2 & 189.8 & 215.1 & 219.2 & 205.7 & 231.3 \\
\hline Protein fed $(g)$ & 477.8 & 283.5 & 618.5 & 1435.8 & 430.7 & 447.2 & 471.8 & 478.2 \\
\hline Productive protein value (PPV, \%) & 26 & 24 & 19 & 13 & 50 & 49 & 44 & 48 \\
\hline
\end{tabular}




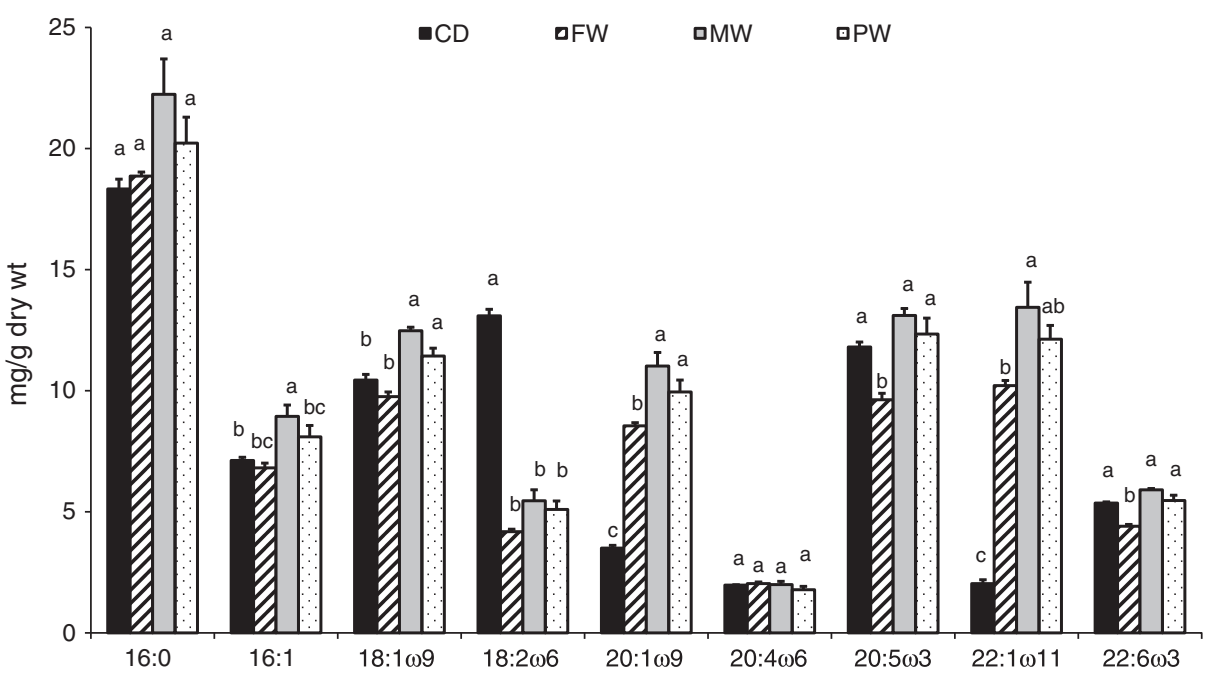

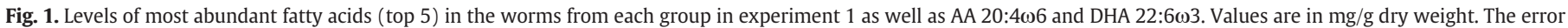
bars are standard error of the means and the different superscripts denote significant differences between treatments (ANOVA, $\mathrm{p}<0.05$ ).

The ratio of $\omega 3: \omega 6$ varied from $1.04 \pm 0.02$ to $2.53 \pm 0.03$ and the DHA:EPA ratio was very similar to experiment 1 , between $0.46 \pm 0.01$ and $0.47 \pm 0.01$ across all groups.

\subsubsection{Proximate and CHN analysis of substrate}

The final proximate and CHN analysis of the sand after the worms were harvested (Table 4 ) shows that there was very little organic content remaining in the sand after removal of the worms.

\section{Discussion}

Both trials demonstrated that $N$. virens can feed successfully on waste from a marine fish recirculation system. In experiment 1 the worms grew best on waste halibut pellets and this is probably due to the higher protein content found in the waste halibut pellets compared to the worm feed. The final biomass and average weights were lowest in the group fed fecal waste but not significantly different from either the CD or MW groups. Although the fecal waste also had a higher protein content on a dry weight basis than the commercial worm diet, this is protein that was not digested by the fish and so may be the less digestible fraction. The drop in temperature during the middle of the trial may explain the slower growth than the second experiment.

Experiment 2 was undertaken to test a practical approach that would likely be used if this waste treatment method were scaled up to a commercial level. Mixed waste could be fed in isolation or mixed with a standard feed formulation depending on availability of wastes and the standing crop of worms. In this trial, there was higher survival and better growth. Water temperature was more stable, varying very little from the target temperature of $18^{\circ} \mathrm{C}$.

The value of this process in terms of both nutrient utilization and potential mitigation of environmental impact comes mainly from the recycling of nitrogenous wastes. The efficient recovery of waste protein is reflected in the high PPVs in experiment 2. Other researchers have reported similar findings. Honda and Kikuchi (2002) calculated nitrogen retention resulting from feeding the polychaete worm, Perinereis nuntia vallata with flounder feces (20\% protein as dry weight), flounder diet (55\% protein as dry weight) and polychaete diet (49\% protein as dry weight). They demonstrated that $46.3 \%, 53.7 \%$ and $53.7 \%$ respectively of the nitrogen fed was retained in the worm body tissue. Nitrogen retention was not reported in the recent study by GarcíaAlonso et al. (2008) but growth was very slow for $N$. diversicolor fed

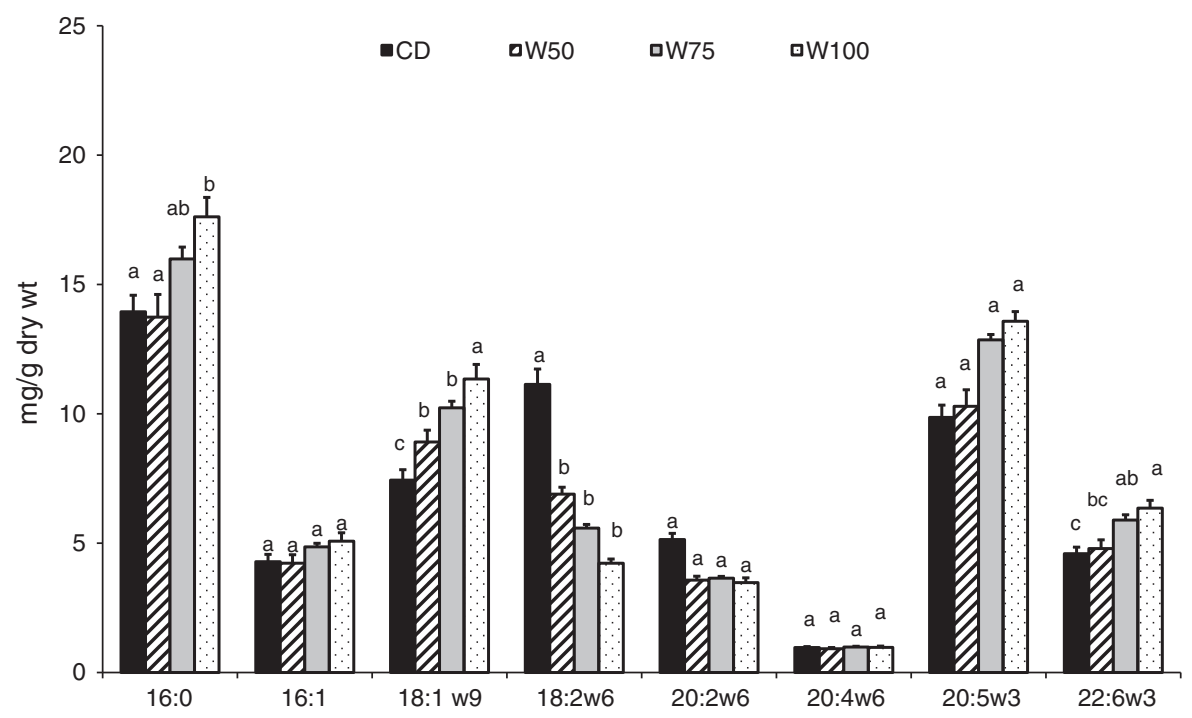

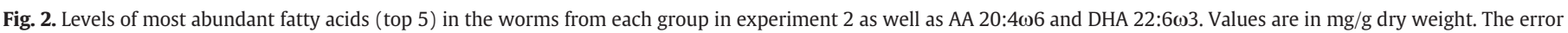
bars are standard error of the means and the different superscripts denote significant differences between treatments (ANOVA, $\mathrm{p}<0.05$ ). 
Table 4

Experiment 2. Proximate analysis and CHN analysis of substrate remaining at the completion of experiment 2. Values for proximate composition are the mean percentages of three replicates. Values for $\mathrm{C}$ and $\mathrm{N}$ are mean percentages of 3 replicates, with 3 samples per replicate. Standard errors of means are shown in parentheses. There were no significant differences detected between treatments (ANOVA, $\mathrm{p}>0.05$ ).

\begin{tabular}{llllll}
\hline & CD & W50 & W75 & W100 & Clean sand \\
\hline Protein (\%) & $0.07(0.02)$ & $0.10(0.02)$ & $0.11(0.02)$ & $0.07(0.00)$ & $0.09(0.00)$ \\
Fat (\%) & $0.20(0.01)$ & $0.00(0.00)$ & $0.08(0.08)$ & $0.19(0.01)$ & $0.17(0.00)$ \\
Ash & $99.00(0.01)$ & $98.94(0.04)$ & $98.91(0.07)$ & $98.98(0.02)$ & $99.26(0.00)$ \\
Acid insoluble & $95.41(0.07)$ & $95.09(0.18)$ & $95.46(0.16)$ & $95.50(0.08)$ & $96.22(0.00)$ \\
$\quad$ ash (\%) & & & & & \\
C (\%) & $0.09(0.01)$ & $0.09(0.01)$ & $0.09(0.00)$ & $0.09(0.00)$ & $0.02(0.00)$ \\
N (\%) & BDL & $<0.070$ & $<0.049$ & $<0.021$ & 0.030 \\
\hline
\end{tabular}

fish feed (205\% over 500 days) whereas for worms fed eel waste there was no growth over the same period. The specific growth rates found in the Honda and Kikuchi study were between 0.45 and $1.66 \%$ day $^{-1}$ for $P$. nuntia vallata fed flounder feces and $3.23 \%$.day $^{-1}$ for worms fed the diet formulated for polychaetes over a 15 day period. In our study, specific growth rates over the course of 71 days were close to $3 \%$.day ${ }^{-1}$ for all treatments in experiment 2 . This also compares favorably with the SGR reported for $N$. virens by Tenore et al. (1974) where the specific growth rate for worms fed oyster feces and pseudofeces was calculated to be $1.04 \%$ day $^{-1}$.

Analysis of the substrate at the conclusion of experiment 2 showed that very little organic matter was left behind. This is important because the substrate can be reused for a future crop but it is disturbed during harvest and any organic matter would have to be contained. This is made easier if there are low levels of carbon and nitrogenous material remaining after harvest.

Worm biomass might be considered as an alternative source of protein for aquaculture feeds providing that the cost of production is not prohibitive. In this way the use of worm beds as a waste treatment method for fish production systems could achieve multiple aims, including the retention of valuable marine lipids from the fish wastes. Total final lipid values found in the worms in our study were similar to other published values for Nereid worms. Promotional literature for Seabait N. virens gives a value of $16 \%$ lipid content. Bischoff et al. (2009) found higher lipid levels than this in their study. They analyzed $N$. diversicolor fed wastes from a recirculating system holding sea bream and compared them to wild worms and found levels of 27.1 and $17.8 \mu \mathrm{g} / \mathrm{mg}$ DW respectively. Studies on wild $N$. diversicolor show that the total fat level varies with the season and is generally higher in the winter (García-Alonso et al., 2008; Luis and Passos, 1995). Thus, the higher fat levels found in the worms in experiment 1 may be related to the lower average water temperatures in this experiment.

Many of the dominant fatty acids found in the worms in this study are commonly abundant in Nereid worms. In particular, 16:0, $18: 1 \omega 9 ; 18: 2 \omega 6$ and $20: 5 \omega 3$ have been found in relatively large amounts in both wild and fed $N$. diversicolor (Fidalgo e Costa et al., 2000; García-Alonso et al., 2008; Luis and Passos 1995). Bischoff et al. (2009) also found high levels of 16:0 and EPA in both wild and waste fed $N$. diversicolor. These authors found AA and DHA absent in the wild worms but present at similar levels to our study in wastefed worms. Differences between treatments in terms of fatty acid profiles in the present study are likely due to differences in relative amounts of vegetable and marine oils used as lipid sources in the commercial worm diet and the halibut diet, though the fatty acid

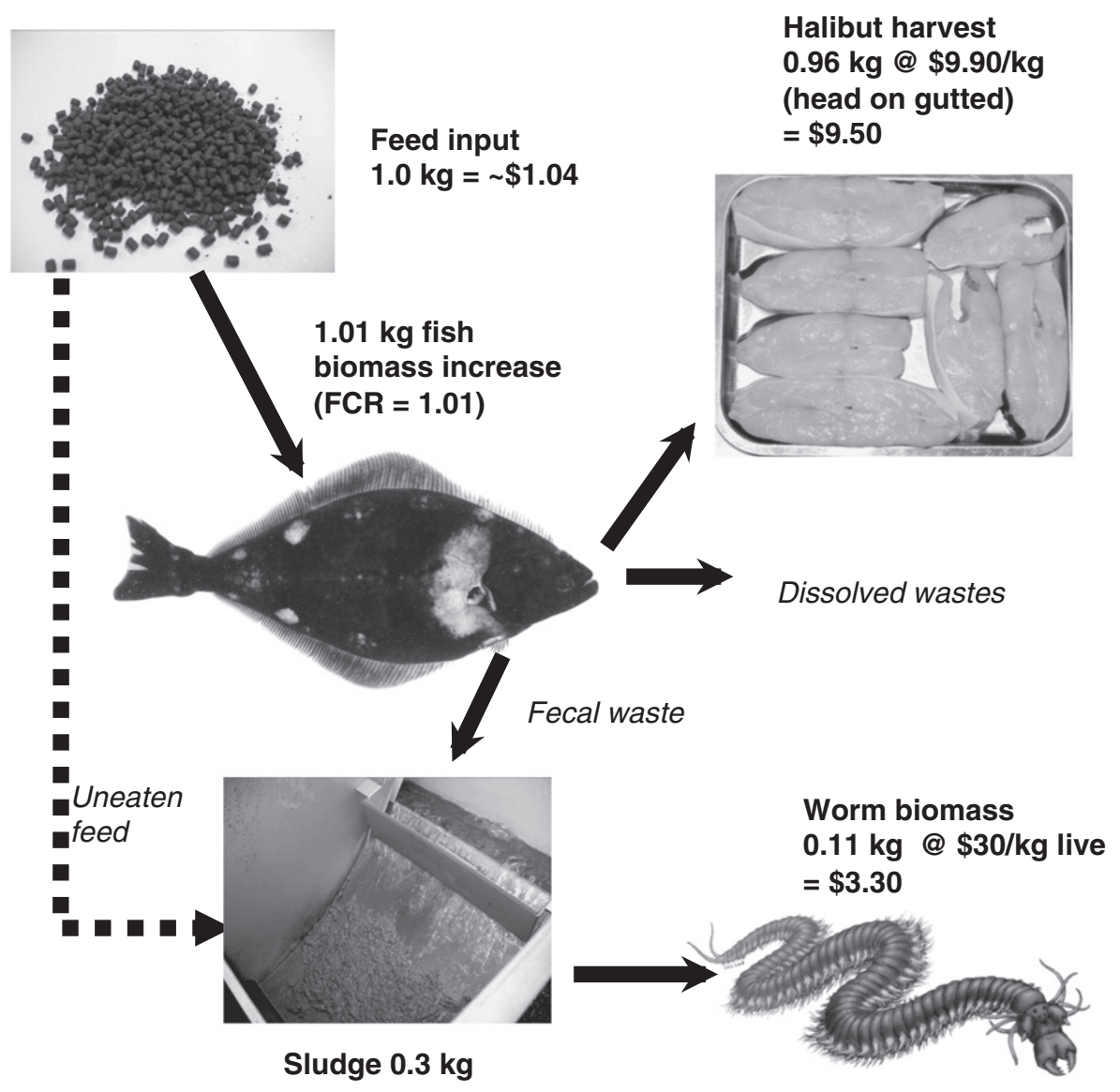

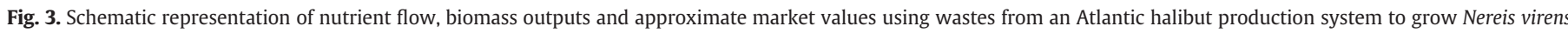
(drawing of Nereis virens by Carrie Graham). 
profiles of these diets were not analyzed. The presence of highly unsaturated fatty acids (HUFAS) such as DHA, EPA and AA greatly enhance the value of these worms as components of fish or shrimp diets. The fact that they can be recovered from fish wastes offers a significant benefit of co-culturing these polychaetes with marine fish in recirculation systems.

During experiment 2, measured changes in halibut biomass, feed input and waste collection data allow us to make some estimates of the biomass of worms that might be produced in an integrated system. Data from the halibut recirculation system indicate that for every $1 \mathrm{~kg}$ of halibut feed used around $1.01 \mathrm{~kg}$ of halibut biomass was produced. From this, $0.295 \mathrm{~kg}$ of sludge (wet weight) was retrieved which included fecal waste and uneaten feed. Using the "wet" FCR figure of 2.68 obtained in this experiment for worms fed only wastes (W100), $0.11 \mathrm{~kg}$ of worm biomass could be grown from this waste. At typical current market values of $\$ 9.9 / \mathrm{kg}$ for halibut and $\$ 30 / \mathrm{kg}$ for sand worm, the respective value of the halibut (head on gutted with 5\% gutting loss) and worms are around $\$ 9.50$ and $\$ 3.30$ respectively for every $\mathrm{kg}$ of fish feed used. The potential improvement in production economics is clear but will depend on the other inputs of labor, facility and energy costs associated with growing the worms (see Fig. 3).

\section{Conclusion}

The polychaete worm, $N$. virens, is an excellent potential candidate for integrated aquaculture in land-based systems. It can grow rapidly on marine fish recirculation system wastes converting them into valuable biomass, which may be a source of food for other aquaculture species.

\section{Acknowledgments}

The study was partly funded by a grant from the Maine Aquaculture Innovation Center. We also appreciate the useful comments of our anonymous reviewers.

\section{References}

AOCS, 2009. Fatty acid composition by GLC: marine oils, Official Methods and Recommended Practices of the AOCS, 6th Edition. AOCS Press, Champaign IL (1200pp.).
Bischoff, A.A., Fink, P., Waller, U., 2009. The fatty acid composition of Nereis diversicolor cultured in an integrated recirculated system: possible implications for aquaculture. Aquaculture 296, 271-276.

D'Asaro, 1976. A preliminary plan for a commercial bait worm hatchery to produce the lugworm, Arenicola cristata (Stimpson). Lugworm aquaculture, report no. 16, State University System of Florida, Sea Grant College Program, pp. 1-46.

Fidalgo e Costa, P., 1999. Reproduction and growth in captivity of the polychaete Nereis diversicolor O. F. Müller, 1776, using two different kinds of sediment: preliminary assays. Boletin Instituto Espanol De Oceanografia 15, 351-355.

Fidalgo e Costa, P., Narciso, L., Cancela da Fonseca, L., 2000. Growth, survival and fatty acid profile of Nereis diversicolor (O. F. Müller, 1776) fed on six different diets. Bulletin of Marine Science 67 (1), 337-343.

García-Alonso, J., Müller, C.T., Hardege, J.D., 2008. Influence of food regimes and seasonality on fatty acid composition in the ragworm. Aquatic Biology 4, 7-13.

Heilskov, A.C. Alperin, M. Holmer, M., 2006. Benthic fauna bio-irrigation effects on nutrient regeneration in fish farm sediments. Journal of Experimental Marine Biology and Ecology 339, 204-225.

Honda, H., Kikuchi, K., 2002. Nitrogen budget of polychaete Perinereis nuntia vallata fed on the feces of Japanese flounder. Fisheries Science 68, 1304-1308.

Izquierdo, M.S., Fernàndez-Palacios, H., Tacon, A.G.J., 2001. Effect of broodstock nutrition on reproductive performance of fish. Aquaculture 197, 25-42.

Kinoshita, K. Tamaki, S., Yoshioka, M., Srithonguthai, S., Kunihiro, T., Hama, D. Ohwada, K., Tsutsumi, H., 2008. Bioremediation of organically enriched sediment deposited below fish farms with artificially mass-cultured colonies of a depositfeeding polychaete Capitella sp. I. Fisheries Science 74, 77-87.

Luis, J.O., Passos, A.M., 1995. Seasonal changes in lipid content and composition of the polychaete Nereis (Hediste) diversicolor. Comparative Biochemistry and Physiology 1B, 579-586.

Lytle, J.S., Lytle, T.F., Ogle, J.T., 1990. Polyunsaturated fatty acid profiles as a comparative tool in assessing maturation diets of Penaeus vannamei. Aquaculture 89, 287-299.

Olive, P.J.W., 1999. Polychaete aquaculture and polychaete science: a mutual synergism. Hydrobiologia 402, 175-183.

Olive, P.J.W., Islam, M.D., Cowin, P.B.D., 2000. Cultured Polychaeta: a dietary resource to increase penaeid hatchery performance. AQUA 2000 Responsible Aquaculture in the New Millenium: EAS Special Publication 28, p. 523 (Nice, May 2-6).

Palmer, PJ. 2010. Polychaete-assisted sand filters. Aquaculture 306, 369-377.

Riise, J.C., Roos, N., 1997. Benthic metabolism and the effects of bioturbation in a fertilized polyculture fish pond in Northeast Thailand. Aquaculture 150 (1-2), 45-62.

Tenore, K.R., Browne, M.G., Chesney, E.R., 1974. Polyspecies aquaculture system: the detrital trophic level. Journal of Marine Research 32, 425-432.

Tomasseti, P., Porrello, S., 2005. Polychaetes as indicators of marine fish farm organic enrichment. Aquaculture International 13, 109-128.

Wouters, R., Lavens, P., Nieto, J., Sorgeloos, P., 2001. Penaeid shrimp broodstock nutrition: an updated review on research and development. Aquaculture 202, 1-21. 